Effects of current velocity on filtration and ... (Apri I. Supii)

\title{
EFFECTSOF CURRENT VELOCITY ON FILTRATION AND INGESTION RATE OF PEARL OYSTER (Pinctada maxima)
}

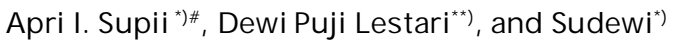 \\ *) Research and Development Institute for Mariculture, Gondol, Bali \\ ${ }^{*}$ Student at Faculty of Fisheries and Marine Science, Diponegoro University
}

(Received 23 J uly 2012; Accepted 2 October 2012)

\begin{abstract}
Pinctada maxima is a filter feeder organism obtaining food particles by filtration from water suspension. Filtration and ingestion rate of a large number of benthic filter feeders in a variety of coastal environment have been known influenced by current velocity. The purposes of this study were to examine the effects of current velocity on filtration and ingestion rate of pearl oyster P. maxima and to determine the best current velocity. Randomized Block Design was used in this experiment with four current treatments of $8,16,24$, and $32 \mathrm{~cm} \mathrm{~s}^{-1}$. The results of this experiment demonstrated that current velocity has a marked effect on filtration rate of $P$. maxima and that this species follows the general pattern of response observed for other bivalves. Different velocity affected filtration and ingestion rate in pearl oyster $P$. maxima. It was gradual decline in the suspension feeding with increasing velocity. Filtration rate of bivalves with siphons facing into the current, were directly inhibited by hydrodynamic effects on the functioning of the bivalves pump. At increasing current velocity, pressures applied to the inhalant and exhalant aperture facing into the flow would result in higher pressures than that of produced by the ciliary pump, resulting in reduced filtration rate. The highest filtration and ingestion rate in this experiment were obtained at velocity of $8 \mathrm{~cm} \mathrm{~s}^{-1}$ that achieved $3.409 \pm 0.485 \mathrm{l} / \mathrm{h}$ and $37.91 \pm 1.27\left(\times 10^{7}\right)$ cells/h, respectively.
\end{abstract}

KEYWORDS: pearl oyster (Pinctada maxima), current velocity, filtration rate, ingestion rate

\section{INTRODUCTION}

Pinctada maxima belong to genus of Pinctada, class of Bivalves that produces a high value pearl. Research and Development Institute for Mariculture (RDIM) Gondol- Bali, Indonesia has developed technology for hatchery seed production of pearl oyster P. maxima. This species is a filter feeder organism obtaining food by filtration or filtering food particles from water suspension. Filtration rate is defined as pumping rate (Riisgård, 2001) and Sebens
(1984) determined the flux of material that can be captured and utilized. A large number of filtration measurements have been performed by indirect filtration method. In an aquarium with bivalves and well- mixed seawater and algal cells, filtration rate is determined from the exponential decrease in algal concentration as a function of time. The filtration method has proved to be a reliable method in many filtration studies on bivalves (Riisgård, 2001). The filtration method first used in Bivalves studies

\# Corresponding author. Research and Development Institute for Mariculture, Jl. Br. Gondol, Kec. Gerokgak, Kab. Buleleng, Kotak Pos 140, Singaraja, Bali 81101, Indonesia. Tel.: +62 36292278 E-mail address: aprisupii@yahoo.co.id 
by Fox et al. (1937) and Jørgensen (1949; 1955). Hereafter, the number of food particles filtered from the suspension by the pearl oysters or feed consumption rate of phytoplankton cells in the digestive tract filtered per unit of time is defined as ingestion rate (Gimin, 2007).

As pearl oyster is a benthic filter feeder organism, it is recognized that physical processes play a key role in controlling the food supply to benthic filter feeders. Such sessile organisms have access only to the water immediately adjacent to the seabed. Filtration and ingestion rate of a large number of benthic filter feeders in a variety of coastal environments have been known influenced by hydrodynamics (Kirby- Smith, 1972; Walne, 1979; Wildish \& Kristmanson, 1997 in Lionel et al., 2007; Leichter \& Witman, 1997; Sobral \& Widdows, 2000; Petersen et al., 2004). The influence has mainly been assessed on active filter feeders (Calahan et al., 1989; Grizzle et al., 1992), studies commonly focusing on the optimal flow characteristics for the feeding behavior of cultured species (Wildish \& Miyares, 1990; Denis et al., 1999). Numerous studies have been conducted on bivalves. This is certainly the case in the 10-12 species of marine and freshwater bivalves in which the effects of velocity has been examined experimentally (Ackerman, 1999). The influence of velocity on feeding behavior was studied on the benthic suspension-feeding Metridium senile and the northern horse mussel Modiolus modiolus (Lesser et al., 1994), Mytilus galloprovincialis (Lionel et al., 1999), Ruditapes decussatus L. (Sobral \&Widdows, 2000), Mytilus trossulus and M. californianus (Ackerman \& Nishizaki, 2004), Cerastoderma edule (Widdows \& Navarro, 2007), and infaunal clam Austrovenus stutchburyi (Jones et al., 2011).

Velocity led to reduced feeding rate, and that species differ in terms of the range of velocities where maximum suspension feeding or growth rates occur. Moreover, results for Mytilus edulis, showed that filtration or filtration rate increased directly with current velocity to $\sim 25 \mathrm{~cm} \mathrm{~s}^{-1}$ beyond which filtration rate declined (Wildish \& Miyares, 1990). However, the feeding response of related bivalve $P$. maxima to current velocity has not been examined. The purposes of this study were to examine the effect of current velocity on filtration and ingestion rate of pearl oyster $P$. maxima and to determine the current veloc- ity that can provide filtration and ingestion rate of P. maxima with the best value. Given the important role this species plays in the ecosystems, results from this study will also provide essential and important information for predicting the current velocity required for the culture activities of pearl oyster P. maxima.

\section{MATERIALS AND METHODS}

\section{Pearl Oysters}

Specimens of $P$. maxima $(6$ to $7 \mathrm{~cm}$ shell length and 50- $71 \mathrm{~g}$ weight, $\mathrm{n}=36$ ) obtained from suspended culture of Research and Development Institute for Mariculture (RDIM) Gondol-Bali, Indonesia. Pearl oysters were cleaned from biofouling and brought into the laboratory. Before the experiment, the pearl oysters were acclimated to experimental diets (Chaetoceros sp.), and temperature in the laboratory for 4 days.

\section{Experimental Device}

Filtration and ingestion rate experiments were performed in small flumes $(75 \mathrm{~cm} \times 40 \mathrm{~cm}$ $\times 25 \mathrm{~cm}$ ) filled with $30 \mathrm{~L}$ seawater under laboratory conditions. The flumes (modified from Tuchman et al., 2004) equipped with water pump (Aquila P 1200, Aquila P 1600, and Aquila $P$ 5200). Water pump immersed in water and connected with hose to the pipe which has 6 holes to produce a horizontal unidirectional current within the flume and then given an insulation of styrofoam slab which has 6 holes (Figure 1). Current velocity was determined using ball flow (ball suspect) (Illahude, 1999). Ball flow released and then following water current at a certain distance and the taken time used to determine the current velocity (Eq. 1).

$\mathrm{V}=\mathrm{S} / \mathrm{t}$

with:

$\mathrm{V}=$ Current velocity $\left(\mathrm{m} \mathrm{s}^{-1}\right)$

$\mathrm{S}=$ Distance $(\mathrm{m})$

$\mathrm{t}=$ Time $(\mathrm{s})$

The pocket net employed in front of the pipe where experimental pearl oysters were contained (Figure 1).

\section{Effects of Current Velocity}

Randomized Block Design was used in this experiment with four current velocities of $8,16,24$, and $32 \mathrm{~cm} \mathrm{~s}^{-1}$. Three replicate trials 


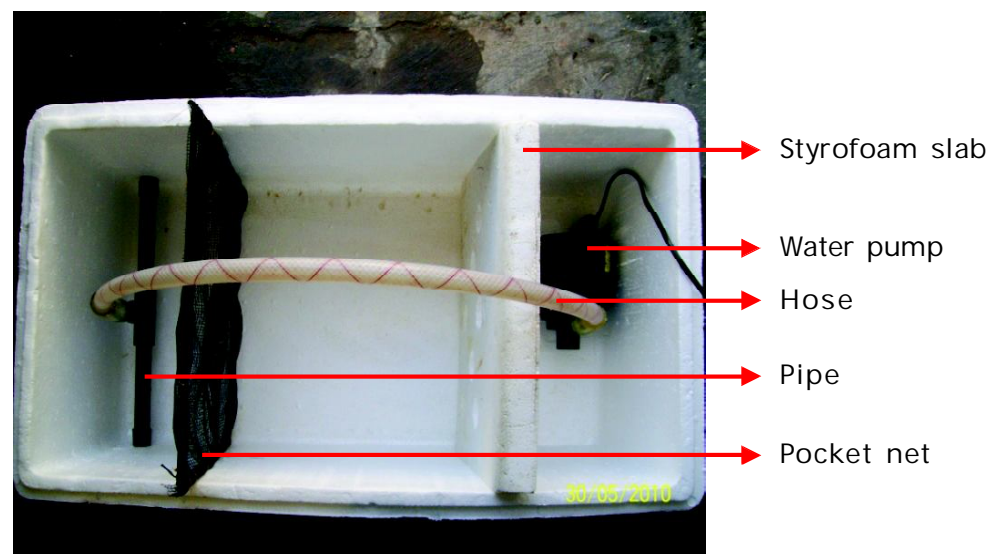

Figurel. Schematics diagram of experimental flume. Each flume had a separate current velocity assigned and the experiment was repeated three times for replication

were conducted for each current velocity. Three pearl oysters were attached to the pocket net in the flume $15 \mathrm{~cm}$ from the pipe with the umbo facing downward, the exhalant siphon facing upward, and the inhalant siphon facing into the current. P. maxima were allowed to acclimate until normal siphoning activity (i.e. opening of valve and protrusion of inhalant and exhalant siphons) it was observed prior to each experiment. Each replicate flume run with a different group of P. maxima $(n=3)$.

Filtration rate is measured as the volume of water cleared of suspended particles per unit of time. The reduction in the number of particles as a function of time is monitored by taking water samples at fixed time intervals and measuring the particle concentration (Coughlan, 1969). Filtration rate was calculated using the following equation (Albentosa et al., 1997; Lora- Vilchis, 2001):

$\mathrm{FR}=\mathrm{V}[\mathrm{Ln}\{\mathrm{Co}-(\mathrm{Co} \times \mathrm{Cc})\}-\mathrm{LnCt}] / \mathrm{nt} . . \quad$ (Eq. 2)

with:

$\mathrm{FR}=$ Filtration rate $\left(\mathrm{I} \mathrm{h}^{-1}\right)$

$\mathrm{V}=$ Volume of water in the flume (I)

$\mathrm{Co}=$ Algal cell concentrations at the beginning of each time increment (cell $\mathrm{ml}^{-1}$ )

$\mathrm{Cc}=$ Algal cell concentrations at the end of each time increment (cell ml-1)

$\mathrm{n}=$ Number of individuals

$\mathrm{t}=$ Time $(\mathrm{h})$

$\mathrm{Cc}=$ Filtration rate variation

$$
\mathrm{Cc}=(\mathrm{Cci}-\mathrm{Cct}) / \mathrm{Cci}
$$

with:

$\mathrm{Cci}=$ Algal cell concentrations at the beginning $\left(t_{0}\right)$ in the flume of control.

Cct $=$ Algal cell concentrations at the end time (t) in the flume of control.

Further, the number of food particles filtered from the suspension by the pearl oysters or feed consumption rate of phytoplankton cells in the digestive tract filtered per unit of time measured as ingestion rate (Gimin, 2007). Ingestion rate was calculated using the following equation (Albentosa et al., 1997, LoraVilchis, 2001):

$\mathrm{IRC}=\mathrm{V}[\{\mathrm{Co}-(\mathrm{Co} \times \mathrm{Cc})\}-\mathrm{Ct}] / \mathrm{nt} \ldots .$.

with:

IRc $=$ Ingestion rate $\left(\right.$ cell $\mathrm{h}^{-1}$ )

$\mathrm{V} \quad=$ Volume of water in the flume (I)

Co $=$ Algal cell concentrations at the beginning of each time increment (cell $\mathrm{ml}^{-1}$ )

$\mathrm{Cc}=$ Algal cell concentrations at the end of each time increment (cell $\mathrm{ml}^{-1}$ )

$\mathrm{n}=$ Number of individuals

$\mathrm{t} \quad=$ Time $(\mathrm{h})$

$\mathrm{Cc}=$ Ingestion rate variation

$$
\mathrm{Cc}=(\mathrm{Cci}-\mathrm{Cct}) / \mathrm{Cci}
$$

with:

$\mathrm{Cci}=$ Algal cell concentrations at the beginning of each time increment $\left(\mathrm{t}_{\mathrm{o}}\right)$ in the control flume

Cct $=$ Agal cell concentrations at the end of each time increment $(t)$ in the control flume 
Pearl oysters were allowed to filter for 3 hours at each current velocity. Filtration and ingestion rate was observed at the first, the second and the third hour. This procedure was then repeated for each current velocity.

\section{Experimental Diet}

Chaetoceros sp. was used as food source for pearl oysters during the experiment. This microalga was cultured in the laboratory of plankton at Research and Development Institute for Mariculture (RIM) Gondol- Bali. Algal cells were introduced into the flume to obtain a concentration of approximately $18 \times 10^{4}$ cells $\mathrm{ml}^{-1}$, for 3 pearl oysters (Sulistiyani, 2005) at each trial. Algal cell concentration was counted with haemocytometer.

\section{Data Analysis}

Data were analyzed using analysis of variance (ANOVA) test to examine the effects of velocity on pearl oyster filtration and ingestion rate. Data of filtration and ingestion rate were log- transformed to meet the ANOVA assumptions of normality. Following significant ANOVA results, Duncan test of multiple regions was used to examine specific differences among different current velocity.

\section{RESULTS AND DISCUSSION}

\section{Results}

\section{Filtration Rate}

The average of P. maxima filtration rate at different current velocities with concentration of diet of $18 \times 10^{4}$ cells $\mathrm{ml}^{-1}$ at the first, the second and the third hour showed in Table 1.

Table 1 shows that filtration rate from the highest to the lowest was in treatment $A$ that achieved $3.40 \pm 0.48 \mathrm{I} \mathrm{h}^{-1}$, followed by B, C, and D treatments, $2.48 \pm 0.521 \mathrm{I} \mathrm{h}^{-1}, 1.58 \pm 0.435 \mathrm{Ih}^{-1}$, and $0.91 \pm 0.237 \mathrm{I} \mathrm{h}^{-1}$, respectively. From the results of normality, homogeneity and additivity tests indicated that the data obtained were normally spread, homogeneous and additive, so that those data meet the assumptions of analysis of variance. Based on the results of ANOVA, showed that different current velocity affected $(P<0.01)$ pearl oyster filtration rate. And then, Duncan test of multiple regions was conducted (Table 2).

Result of Duncan test of multiple regions showed that treatment $A$ was significantly different from treatments $B, C$, and $D$; treatment $B$ was significantly different from treatments $C$ and $D$; and treatment $C$ was significantly different from treatment $D$.

\section{Ingestion Rate}

The average of $P$. maxima ingestion rate at different current velocities with concentration of diet of $18 \times 10^{4}$ cell $\mathrm{ml}^{-1}$ showed in Table 3.

Table 3 shows that ingestion rate from the highest to the lowest was in treatment $A$ which achieved $37.91 \pm 1.27$ (cells $\left.\mathrm{h}^{-1}\right)\left(10^{7}\right)$ followed by treatment $B, C$, and $D, 31.25 \pm 1.15$ (cells $\left.\mathrm{h}^{-1}\right)\left(10^{7}\right), 22.49 \pm 0.99$ (cells $\left.\mathrm{h}^{-1}\right)\left(10^{7}\right)$, and

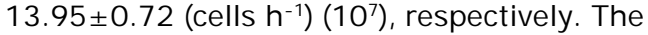
results of normality, homogeneity and additivity test showed that the data obtained were normally spread, homogeneous and additive so that those data meet the assumptions of analysis of variance. Based on analysis of variance results showed that different current velocity affected $(P<0.01)$ pearl oyster ingestion rate. Furthermore, Duncan test of multiple regions was conducted (Table 4 ).

Result of Duncan test of multiple regions showed that treatment $A$ did not differ from $B$ treatment but significantly different from $C$ and D treatment; B treatment did not differ from C

Table 1. Mean of P. maxima filtration rate $\left(\mathrm{h} \mathrm{h}^{-1}\right)$ at different current velocities

\begin{tabular}{|c|c|c|c|c|}
\hline \multirow{2}{*}{ Time } & \multicolumn{4}{|c|}{ Current velocity } \\
\hline & $A\left(8 \mathrm{~cm} \mathrm{~s}^{-1}\right)$ & $B\left(16 \mathrm{~cm} \mathrm{~s}^{-1}\right)$ & $C\left(24 \mathrm{~cm} \mathrm{~s}^{-1}\right)$ & D $\left(32 \mathrm{~cm} \mathrm{~s}^{-1}\right)$ \\
\hline First hour & $3.96 \pm 0.67$ & $3.07 \pm 0.65$ & $2.04 \pm 0.51$ & $1.18 \pm 0.46$ \\
\hline Second hour & $3.15 \pm 0.61$ & $2.23 \pm 0.51$ & $1.52 \pm 0.27$ & $0.78 \pm 0.38$ \\
\hline Third hour & $3.10 \pm 0.63$ & $2.12 \pm 0.46$ & $1.17 \pm 0.45$ & $0.75 \pm 0.74$ \\
\hline Means $\pm S D$ & $3.40 \pm 0.48$ & $2.48 \pm 0.52$ & $1.58 \pm 0.43$ & $0.91 \pm 0.24$ \\
\hline
\end{tabular}


Effects of current velocity on filtration and ... (Apri I. Supii)

Table 2. Duncan test of multiple regions of pearl oyster (P. maxima) filtration rate

\begin{tabular}{|c|c|c|c|c|c|}
\hline Current velocity & Mean & \multicolumn{4}{|c|}{ Mean difference } \\
\hline$A\left(8 \mathrm{cms}^{-1}\right)$ & $3.40 \pm 0.48$ & $A$ & & & \\
\hline $\mathrm{B}\left(16 \mathrm{cms}^{-1}\right)$ & $2.48 \pm 0.52$ & $0.92^{* *}$ & $\mathrm{~B}$ & & \\
\hline$C\left(24 \mathrm{cms}^{-1}\right)$ & $1.58 \pm 0.43$ & $1.82^{* *}$ & $0.90^{* *}$ & $\mathrm{C}$ & \\
\hline $\mathrm{D}\left(32 \mathrm{cms}^{-1}\right)$ & $0.91 \pm 0.24$ & $2.49^{* *}$ & $1.57^{* *}$ & $0.67^{*}$ & $\mathrm{D}$ \\
\hline
\end{tabular}

** $=$ Significantly different

Table 3. Mean of P. maxima ingestion rate (cells $\left.\mathrm{h}^{-1}\right)\left(10^{7}\right)$ at different current velocity

\begin{tabular}{|c|c|c|c|c|}
\hline \multirow{2}{*}{ Time } & \multicolumn{4}{|c|}{ Current velocity } \\
\hline & $A\left(8 \mathrm{~cm} \mathrm{~s}^{-1}\right)$ & B $\left(16 \mathrm{~cm} \mathrm{~s}^{-1}\right)$ & $C\left(24 \mathrm{~cm} \mathrm{~s}^{-1}\right)$ & $D\left(32 \mathrm{~cm} \mathrm{~s}^{-1}\right)$ \\
\hline First hour & $58.75 \pm 8.29$ & $47.5 \pm 8.66$ & $33.12 \pm 7.73$ & $20.00 \pm 7.35$ \\
\hline Second hour & $32.50 \pm 4.56$ & $26.25 \pm 4.33$ & $20.62 \pm 3.14$ & $11.87 \pm 5.15$ \\
\hline Third hour & $22.50 \pm 2.04$ & $20.00 \pm 2.04$ & $13.75 \pm 4.33$ & $10.00 \pm 8.41$ \\
\hline Means $\pm S D$ & $37.91 \pm 1.27$ & $31.25 \pm 1.15$ & $22.49 \pm 0.99$ & $13.95 \pm 0.72$ \\
\hline
\end{tabular}

Table 4. Duncan test of multiple regions of pearl oyster (P. maxima) ingestion rate

\begin{tabular}{lccccc}
\hline \multicolumn{1}{c}{ Current velocity } & Mean & \multicolumn{3}{c}{ Mean difference } \\
\hline A $\left(8 \mathrm{~cm} \mathrm{~s}^{-1}\right)$ & $37.91 \pm 1.27$ & A & & & \\
B $\left(16 \mathrm{~cm} \mathrm{~s}^{-1}\right)$ & $31.25 \pm 1.15$ & 6.67 & $\mathrm{~B}$ & & \\
C $\left(24 \mathrm{~cm} \mathrm{~s}^{-1}\right)$ & $22.49 \pm 0.99$ & $15.42^{*}$ & 8.75 & $\mathrm{C}$ & \\
D $\left(32 \mathrm{~cm} \mathrm{~s}^{-1}\right)$ & $13.95 \pm 0.72$ & $23.96^{* *}$ & $17.29^{*}$ & 8.54 & $\mathrm{D}$ \\
\hline$* *$ & & & &
\end{tabular}

treatment but significantly different from D treatment; and $C$ treatment did not differ from $\mathrm{D}$ treatment, either.

\section{DISCUSSION}

\section{Filtration Rate}

It is proven that fluid dynamic factors, current velocity in this case, had important effect on filtration rate of pearl oyster P. maxima although important species-specific differences were also found. The results of this experiment demonstrated that current velocity had a marked effect on filtration rate of $P$. maxima and that this species follows the general pattern of response observed for other bivalves. Previous studies have recorded a similar gradual decline in the suspension feed- ing and/ or growth of bivalves with increasing current velocity from 1 to $>15 \mathrm{~cm} \mathrm{~s}^{-1}$ in mussel M. edulis (Wildish \& Miyares, 1990), giant scallop Placopecten magellanicus (Wildish et al., 1987) and (Wildish et al., 1992), bay scallop Argopecten irradians (Kirby- Smith, 1972) and (Cahalan et al., 1989), Ruditapes decussates (Sobral \& Widdows, 2000), (MacKenzie et al., 1994), (Ackerman, 1999) and (Peters \& Marrasé, 2000). Lesser et al. (1994) also stated that higher fluxes, however, do not always give positive results, in which benthic suspension feeders responded both positively and negatively as current velocity increased. Nonsiphonate bivalve molluscs generally show a negative effect of increasing current velocity on filtration or filtration rate (Cahalan et al., 1989). Moreover, particles are directed towards the mouth by ciliary motions which may be 
affected by high current velocities (Ward et al., 2003) or a bypass of the gill structure (Wildish et al., 1987; Wildish \& Saulnier, 1993).

The filtration rate of mussel Mytilus edulis was approximately $70 \%$ lower at $30 \mathrm{~cm} \mathrm{~s}^{-1}$ than at $10 \mathrm{~cm} \mathrm{~s}^{-1}$ (Newell et al., 2001). Mussels decrease their filtration rate as the current velocity increase from 10 to $30 \mathrm{~cm} \mathrm{~s}^{-1}$. At low velocities $\left(0-5 \mathrm{~cm} \mathrm{~s}^{-1}\right)$, filtration rate are flowlimited indirectly due to the effects of reductions in ambient particle concentrations from local refiltration (Wildish \& Miyares, 1990). On one hand, increasing current velocity has been shown to compensate the effects of particle depletion by replacing the seston- depleted water with a new source of seston. Grizzle et al. (1992), found a positive correlation between current velocity and growth in Mercenaria mercenaria for velocity of $2-8 \mathrm{~cm}$ $\mathrm{s}^{-1}$ with maximum growth at $2-4 \mathrm{~cm} \mathrm{~s}^{-1}$ and decreased growth in Crassostrea virginica at low velocity $\left(1 \mathrm{~cm} \mathrm{~s}^{-1}\right)$. In this range, the hydrodynamic forcing applied on organisms allows filtration processes to proceed up to an optimum rate, but for higher current velocities, water motion becomes a stress source, affecting the efficiency of the filtration system and the energy yielded (Wildish \& Kristmanson, 1997 in Lionel et al., 2007). Filtration rate of bivalves, with siphons facing into the current, are directly inhibited by hydrodynamic effects on the functioning of the bivalves pump (Eckman et al., 1989), (Wildish \& Saulnier, 1992) and (Wildish \& Saulnier, 1993). At increasing current velocity, pressures applied to the inhalant (Wildish \& Miyares, 1990, Newell et al., 2001) or to the exhalant (Wildish \& Saulnier, 1993) and (Eckman et al., 1989) aperture facing into the current would result in higher pressures than produced by the ciliary pump, result in slower growth rates or reduced filtration rate. Newell et al., (2001) studied the effects of velocity on exhalant siphon area and valve gape in mussel Mytilus edulis. An increase in current velocity from 10 to $30 \mathrm{~cm} \mathrm{~s}^{-1}$ caused a highly significant linear decrease in exhalant siphon area but not a significant decrease in valve gape.

Filtration rate are a unimodal function of current velocity. Below $5-10 \mathrm{~cm} \mathrm{~s}^{-1}$ there is a positive relationship between current velocity and filtration rate as increasing velocity removes localized envelopes of seston depleted water around individuals. Filtration rate are independent of velocity at intermediate at speeds (10-20 $\mathrm{cm} \mathrm{s}^{-1}$ ) since particle capture rates are determined by the internal currents generated by the bivalve pump and particle concentration. Further increases in current velocity above $15-20 \mathrm{~cm} \mathrm{~s}^{-1}$ cause a decline in feeding rate until pumping ceases all together (Rubenstein \& Koehl, 1977; Eckman et al., 1989; Cahalan et al., 1989). But in our study did not perform the filtration rate at current velocity below $8 \mathrm{~cm} \mathrm{~s}^{-1}$ because the conditions of water pump which can not produce the current velocity below $8 \mathrm{~cm} \mathrm{~s}^{-1}$.

Filtration rate at the first, the second, and the third hour showed the decreasing values. At the first hour obtained the highest filtration rate compared to the second and the third hour. Filtration rate at the second and the third hour were relatively stable. Decreased filtration rate relates to the decline in the concentration of microalga and the saturation concentration of the feed in the stomach. According to Mason (1983), scallop has a rest period in filtering food resulting in decline in filtration rate.

Although filtration rate measured by means of the filtration method of Eq. (2), but generally seems to be reliable, high algal concentrations may cause saturation of the alimentary canal and the bivalves close their valves and restrict the filtration rate: saturation reduction (Riisgård, 2001). This phenomenon may explain low filtration rate reported for Mercenaria mercenaria and Ostrea edulis by Walne (1972), Mytilus edulis by Winter (1973) and Schulte (1975), for Crassostrea gigas by Gerdes (1983), and for Tapes philippinarum by Coutteau et al. (1994). Filtration rate as a function of algal concentration, up to 100,000 Chaetoceros neogracile cells $\mathrm{ml}^{-1}$, was studied in $\mathrm{T}$. philippinarum by Coutteau et al. (1994), who measured a maximum filtration rate of 2.3 | g-1 ${ }^{\mathrm{h}-1}$ and an incipient limiting concentration of about 25, 000 cells $\mathrm{ml}^{-1}$, far above most natural biomass levels of phytoplankton.

Toward this end, future studies should couple filtration rate measurement with physiological processes, such as levels of gut fullness and digestive cycles that operate over longer time periods (Pilditch \& Grant, 1999). Moreover, quantifying the time scale over which bivalves are integrating past conditions will also be crucial to providing better predictions of bivalve feeding behaviour and growth (Bayne, 1993 in Pilditch \& Grant, 1999). 


\section{Ingestion Rate}

The highest ingestion rate of pearl oyster is on treatment $A$, because of filtration rate results are also achieved the highest value in treatment $A$. Therefore, in times of high filtration rate, ingestion rate is also high. Gimin (2007), also report that higher ingestion rate occurred in times of high filtration rate in mangrove oyster Polymesoda erosa that is 41.07 $\left(10^{7}\right)$ cell $\mathrm{h}^{-1}$ at the time of filtration rate reached $2.5 \mathrm{Ih}^{-1}$.

Duncan test of multiple regions showed that treatment $A$ was not different from treatment $B$, which indicate that the total mass of feed in the digestive tract was relatively the same. Similarities in the mass of microalga that was ingested, showed that ingestion process in pearl oyster was limited by the capacity of digestive tract. The difference in filtration rate but the ingestion rate were the same in several treatments indicated that bivalves were able to regulate the physiology process to achieve a constant ingestion rate (Gimin, 2007). In this experiment, the best filtration and ingestion rate were obtained at the current velocity of $8 \mathrm{~cm} \mathrm{~s}^{-1}$.

Basically, the higher concentration of particles the higher the value of filtration rate, but the ingestion rate or the ability of the stomach to accommodate food is limited by the size and speed of the stomach to digest food. The declining of ingestion rate at the second and the third hour in this study because of the rest period of filtering and reach satiation or until the digestion capacity filled with microalga. Laing (2004), reported that king scallop (Pecten maximus) decreases the filtration process when the satiation reached. This effect, seen in other bivalves, is a result of saturation of the alimentary canal, causing the animals to close their valves and restrict the filtration rate.

As the effect of current velocity on ingestion rate also depends on particle concentrations, Grizzle \& Lutz (1988) suggested that food flux (e.g. velocity $x$ particles concentration) is a better predictor of growth rather than the separate parameters. In our study, only the influence of current velocity was explored, and complementary experiments are still needed for a better understanding of $P$. maxima ingestion activity, such as the quantity and quality of food, and the balance between inorganic and organic particles in the water column.

\section{CONCLUSION}

Different current velocity affected the filtration and ingestion rate in the pearl oyster $P$. maxima. The highest filtration and ingestion rate in this experiment were obtained at the current velocity of $8 \mathrm{~cm} \mathrm{~s}^{-1}$ that achieved $3.409 \pm 0.485 \mathrm{~L} / \mathrm{h}$ and $37.91 \pm 1.27\left(\times 10^{7}\right)$ cells $/ \mathrm{h}$ for the each filtration and ingestion rate.

\section{ACKNOWLEGEMENTS}

The authors are grateful to Ketut M. Arya Sudewa for providing algal culture, Syamsul Fajar Gumilar, and Dadang Rusmana for their help during preparation and the experiment. Moreover, the author would like to thank to anonymous reviewers who amply contributed to the improvement of this manuscript.

\section{REFERENCES}

Ackerman, D.J. 1999. The effect of velocity on the filter feeding of zebra mussels (Dreissena polymorpha and D. bugensis): implications for trophic dynamics. Canadian Journal of Fisheries and Aquatic Sciences, 56: 1,551- 1,561.

Ackerman, J.D. \& Nishizaki, M.T. 2004. The effect of velocity on the suspension feeding and growth of the marine mussels Mytilus trossulus and M. californianus: implications for niche separation. Journal of Marine Systems. Volume 49, Issues 1-4, August 2004, p. 195- 207.

Albentosa, M., Perez- Camacho, S., Labarta, U., \& Fernandez-Reiriz, M.J. 1997. Evaluation of freeze dried microalgal diets for the seed culture of Ruditapes decussatus using physiological and biochemical parameters. Aquaculture, 154: 305- 321.

Cahalan, J.E., Siddall, S.E., \& Luckenbach, M.W. 1989. Effects of current velocity, food concentration and particle flux on growth rates of juvenile bay scallops Argopecten irradians. J. Exp. Mar. Biol. Ecol., 129: 4560.

Coughlan, J. 1969. The estimation of filtering rate from the filtration of suspensions. Mar Biol., 2: 356- 358.

Coutteau, P., Curé, K., \& Sorgeloos, P. 1994. Effect of algal ration on feeding and growth of juvenile manila clam Tapes philippinarium (Adams and Reeve). J. Shellfish Res., 13: 4755.

Denis, L., Alliot, E., \& Grzebyk, D. 1999. Filtration rate responses of mediterranean mus- 
sels, Mytilus galloprovincialis, to variations in the flow, water temperature, food quality and quantity. Aquat. Liv. Res., 12: 279288.

Eckman, J.E., Peterson, C.H., \& Calahan, J.A. 1989. Effects of flow speed, turbulence, and orientation on growth of juvenile bay scallops, Argopecten ir radians concentricus (Say). J. Exp. Mar. Biol. Ecol., 132: 123- 140.

Fox, D.L., Sverdrup, H.U., \& Cunningham, J.P. 1937. The rate of water propulsion by the California Mussel. Biol. Bull., 72: 417- 438.

Gerdes, D. 1983. The pacific oyster Crassostrea gigas. Part I. Feeding behaviour of larvae and adults. Aquaculture, 31: 195- 219.

Gimin, R. 2007. Filtrasi, ingesti, assimilasi dan perolehan energi pada kerang bakau Polymesoda erosa yang diberi pakan berbagai spesies mikroalga. Prosiding Seminar Nasional Tahunan Perikanan dan Kelautan. UGM.

Grizzle, R.E. \& Lutz, R.A. 1988. A statistical model relating horizontal seston fluxes and bottom sediments characteristics to the growth of Mercenaria mercenaria. Mar. Biol., 102: 95- 105.

Grizzle, R.E., Langan, R., Huntting, \& Howell, W. 1992. Growth responses of suspensionfeeding bivalve molluscs to changes in water flow: differences between siphonate and nonsiphonate taxa. J. Exp. Mar. Biol. Ecol., 162: 213- 228.

Illahude, A.G. 1999. Pengantar Oceanografi Fisika. Puslitbang Oceanografi, LIPI. Jakarta, hlm. 7- 18.

Jones, H.F.E., Pilditch, C.A., Bryan, K.R., \& Hamilton, D.P. 2011. Effects of infaunal bivalve density and flow speed on filtration rate and near- bed hydrodynamics. Journal of Experimental Marine Biology and Ecology. Volume 401, Issues 1- 2, 31 May 2011, p. 20- 28.

Jørgensen, C.B. 1949. The rate of feeding by Mytilus in different kinds of suspension. J Mar Biol Assoc UK, 28: 334- 344.

Jørgensen, C.B. 1955. Quantitative aspects of filter feeding in invertebrates. Biol. Rev., 30: 391- 454.

Kirby- Smith, W.W. 1972. Growth of the bay scallop: the influence of experimental water currents. J. Exp. Mar. Biol. Ecol., 8: 7- 18.

Laing, I. 2004. Filtration of king scallops (Pecten maximus). Aquaculture Volume 240, Issues 1- 4, 27 October 2004, p. 369- 384.
Leichter, J.J. \& Witman, J.D. 1997. Water flow over subtidal rock walls: relation to distributions and growth rates of sessile suspension feeders in the Gulf of Maine water flow and growth rates. Journal of Experimental Marine Biology and Ecology Volume 209, Issues 1- 2, 3 February 1997, p. 293307.

Lesser, M.P., Witman, J.D., \& Sebens, K.P. 1994. Effects of flow and seston availability on scope for growth of benthic suspensionfeeding invertebrates from the Gulf of Maine. Bid. Bull., 187: 319- 335.

Lionel, D., Alliot, E. , \& Grzebyk, D. 1999. Filtration rate responses of Mediterranean Mussels, Mytilus galloprovincial is, to variations in the flow, water temperature, food quality and quantity. Aquatic Living Resources Volume 12, Issue 4, July 1999, p. 279- 288.

Lionel, D., Nicolas, D., \& Michel, R. 2007. Ambient current velocity and resulting filtration rate of the terebellid polychaete Lanice conchilega (Pallas, 1766). Journal of Sea Research Volume 58, Issue 3, October 2007, p. 209- 219.

Lora- Vilchis, M.C. \& Doktor, N. 2001. Evaluation of seven algal diets for spat of the Pacific Scallop Argopecten ventricosus. Journal of the World Aquaculture Society, (32): 228235.

MacKenzie, B.R., Miller, T.J., Cyr, S., \& Leggett, W.C. 1994. Evidence for a dome-shaped relationship between turbulence and larval fish ingestion. Limnology and Oceanography, 39: 1,790- 1,799.

Mason, J. 1983. Scallop and Queen Fiseheries in the British Isles. Fishing News Book Ltd. Farnham Surrey England, $143 \mathrm{pp}$.

Newell, C. R., Wildish, D.J., \& MacDonald, B.A. 2001. The effects of velocity and seston concentration on the exhalant siphon area, valve gape and filtration rate of the mussel Mytilus edulis. Journal of Experimental Marine Biology and Ecology, Volume 262, Issue 1, 15 July 2001, p. 91- 111.

Peters, F. \& Marrasé, C. 2000. Effects of turbulence on plankton: an overview of experimental evidence and some theoretical considerations. Marine Ecology Progress Series, 205(2000): 291- 306.

Petersen, J.K., Bougrier, S., Smaal, A.C., Garen, P., Robert, S., Larsen, J.E.N., \& Brummelhuis, E. 2004. Intercallibration of mussel Mytilus edulis clearance rate measurement. Marine Ecology Progress Series, 267: 187- 194. 
Pilditch, C.A. \& Grant, J. 1999. Effect of variations in current velocity and phytoplankton concentration on sea scallop (Placopecten magellanicus) grazing rates. Journal of Experimental Marine Biology and Ecology. Volume 240, Issue 1, 1 July 1999, p. 111- 136

Riisgård, H.U. 2001. On measurement of filtration rate in bivalves- the stony road to reliable data:review and interpretation. Marine Ecology Progress Series, 211: 275- 291.

Rubenstein, D.I. \& Koehl, M.A.R. 1977. The mechanisms of filter feeding: some theoretical considerations. Am. Nat., 111: 981994.

Schulte, E.H. 1975. Influence of algal concentration and temperature on the filtration rate of Mytilus edulis. Mar. Biol., 30: 331- 341.

Sebens, K.P. 1984. Water flow and coral colony size: interhabitat comparisons of the octocoral Alcyonium siderium. Proc. Natl. Acad. Sci. USA, 81: 5,473-5,477.

Sobral, P. \&Widdows, J. 2000. Effects of increasing current velocity, turbidity and particlesize selection on the feeding activity and scope for growth of Ruditapes decussatus from Ria Formosa, southern Portugal. J. Exp. Mar. Biol. Ecol., 245: 111- 125.

Sulistyani, Y., Widowati, I., Dwiono, A.P., \& Suprijanto, J. 2005. Filtration rate tiram mutiara (P. maxima dari perairan Lombok, NTB. Seminar Nasional Tahunan Perikanan dan Kelautan UGM.

Tuchman, N.C., Burks, R.L., Call, C.A. , \&Smarrelli, J. 2004. Flow rate and vertical position influence ingestion rate of Colonial Zebra Mussels (Dreissena polymorpha). Freshwater Biology, 49: 191- 198.

Walne, P.R. 1972. The influence of current speed, body size and water temperature on the filtration rate of five species of bivalves. J. Mar. Biol. Assoc. UK, 52: 345374.

Ward, J.E., Levinton, J.S., \& Shumway, S.E. 2003. Influence of diet on pre- ingestive particle processing in bivalves. I: Transport velocities on the ctenidium. J. Exp. Mar. Biol. Ecol., 293: 129- 149.

Widdows, J. \& Navarro, J.M. 2007. Influence of current speed on filtration rate, algal cell depletion in the water column and resuspension of biodeposits of cockles (Cerastoderma edule). Journal of Experimental Marine Biology and Ecology, Volume 343, Issue 1, 30 April 2007, p. 44- 51.

Wildish, D.J., Kristmanson, D.D., Hoar, R.L, Decoste, A.M., McCormick, S.D., \& White, A.W. 1987. Giant scallop feeding and responses to flow. J. Exp. Mar. Biol. Ecol., 113: 207- 220.

Wildish, D.J. \& Miyares, M.P. 1990. Filtration rate of blue mussels as a function of current velocity: preliminary experiments. J. Exp. Mar. Biol. Ecol., 142: 2 13- 219.

Wildish, D.J., Kristmanson, D.D., \&Saulnier, A.M. 1992. Interactive effect of velocity and seston concentration on giant scallop feeding inhibition. J. Exp. Mar. Biol. Ecol., 155: 161- 168.

Wildish, D.J. \& Saulnier, A.M. 1992. The effect of velocity and flow direction on the growth rate of juvenile and adult sea scallops. J. Exp. Mar. Biol. Ecol., 155: 133- 143.

Wildish, D.J. \& Saulnier, A.M. 1993. Hydrodynamic control of filtration in Placopecten magellanicus. J. Exp. Mar. Biol. Ecol., 174: 65-82.

Winter, J.E. 1973. The filtration rate of Mytilus edulis and its dependence on algal concentration, measured by continuous automatic recording apparatus. Mar. Biol., 22: 317- 328. 